\title{
LA CELEBRACIÓN INSTITUCIONAL DE FESTIVIDADES RELIGIOSAS. ANÁLISIS EXCLUSIVAMENTE CONSTITUCIONAL
}

\author{
POR \\ ABRAHAM BARRERO ORTEGA \\ Profesor Contratado Doctor. Departamento de Derecho \\ Constitucional. Universidad de Sevilla
}

\section{INTRODUCCIÓN}

Es sabido que el desconocimiento de la libertad religiosa a lo largo de gran parte de nuestra historia constitucional eclipsó el nacimiento y consolidación del tipo Estado Constitucional ${ }^{1}$ en España. La confesionalidad católica asumida por la Constitución de 1812 marcaría el futuro de nuestro Estado liberal en asuntos de conciencia y religión. La noción moderna de laicismo, que incorpora no sólo la distinción entre la Iglesia y el Estado sino también la concepción de la Iglesia como asociación voluntaria de fieles ${ }^{2}$, sería ignorada por las Constituciones doctrinarias de 1837,1845 y 1876 . El poder político se atreverá a expresar juicios sobre la religión, pues se considera competente para dar defini-

1 En el sentido de HÄBERLE, P., Libertad, igualdad y fraternidad. 1789 como historia, actualidad y futuro del Estado Constitucional, Minima Trotta, Madrid 1998.

2 LOCKE, J., Carta sobre la tolerancia (Edición a cargo de Pedro Bravo Gala), Tecnos, Madrid 1988, p. 23. 
ciones de fe; la Iglesia, por su parte, extenderá su autoridad más allá de la esfera espiritual que le es propia. Las Constituciones de 1869 y 1931, en cambio, significaron cambios ostensibles frente a esta tradición. La primera, implantaría una tolerancia efectiva a favor de los cultos no católicos, los llamados por entonces cultos disidentes; la segunda, siguiendo al proyecto constitucional republicano de 1873, decretará la separación entre el Estado y la Iglesia. No obstante, en ella se introdujo algún precepto abiertamente hostil contra la Iglesia católica que, en última instancia, atentaba contra la dimensión comunitaria de su libertad religiosa. Las confesiones quedaron sometidas a un Derecho especial desfavorable que, a partir de una concepción depresiva de la libertad de religión, coartaba su autonomía de organización y obstaculizaba el libre ejercicio de sus derechos colectivos ${ }^{3}$.

Consciente de todo ello, el constituyente de 1978 fundó las relaciones Estado-Iglesias sobre bases novedosas y a la altura del Derecho Internacional de los Derechos Humanos ${ }^{4}$. Las líneas maestras del consenso constitucional, expresadas en el artículo $16 \mathrm{CE}$, son las siguientes:

a) El reconocimiento de las libertades ideológica y religiosa como derechos fundamentales "de los individuos y de las comunidades" (art. 16.1).

b) La privacidad de las creencias como garantía de la intimidad e igualdad religiosa, puesto que «nadie podrá ser obligado a declarar sobre su ideología, religión o creencias" (art. 16.2).

c) La laicidad del Estado, en tanto consecuencia orgánica de la libertad de religión, ya que «ninguna confesión tendrá carácter estatal» (art. 16.3).

d) La toma de conciencia del factor religioso por parte de los poderes públicos, en la medida en que se les impone el deber de "tener en cuenta las creencias de la sociedad española» (art. 16.3).

e) Las relaciones de cooperación «con la Iglesia Católica y el resto de confesiones" (art. 16.3 in fine), en tanto concreción para el

${ }^{3}$ Sobre todo ello, Tomás y Valiente, F., "Estado e Iglesia, 1808-1978», Constitución: escritos de introducción histórica (Prólogo de Bartolomé Clavero), Marcial Pons, Madrid 1996, pp. 115-148.

${ }^{4}$ En expresión de Carrillo Salcedo, J. A., Soberanía de los Estados y Derechos Humanos en el Derecho Internacional contemporáneo, Tecnos, Madrid 2001. 
ámbito religioso del mandato general de promoción de los derechos fundamentales sentado en el artículo 9.2 CE.

Poco tiempo después, en 1980, la Ley Orgánica 7/1980, de 5 de julio, de Libertad Religiosa, ampliamente apoyada por todos los grupos parlamentarios, certificó la profunda revisión de las relaciones EstadoIglesias en nuestro país. La nueva Ley de Libertad Religiosa de 1980 vino a superar con nitidez el sistema de mera tolerancia de su predecesora, la Ley de Libertad Religiosa de 1967, y, desde entonces, ofrece un amplio y generoso campo para la libertad y la igualdad de los individuos y de los grupos que, social y jurídicamente, merezcan la consideración de confesiones religiosas ${ }^{5}$.

En 1992, y tras haber obtenido el reconocimiento del notorio arraigo exigido por la Ley de 1980, las tres grandes confesiones que, con el Catolicismo, han sido parte integrante de nuestra historia, el Islam, el Judaísmo y la Evangélica, firmaron con el Estado unos acuerdos de cooperación que, en principio, vinieron a desarrollar o, mejor dicho, a concretar las previsiones generales de la Ley en atención a las peculiaridades de cada uno de estos grupos confesionales ${ }^{6}$. No se olvide que, desde 1979, la Iglesia católica ya tenía suscritos diversos acuerdos con el Estado español ${ }^{7}$, de suerte tal que la lógica del sistema constitucional $y$, en concreto, del principio de igualdad obligó a dispensar también un tratamiento jurídico singular a las denominadas confesiones minoritarias, aun de notorio arraigo. En los años subsiguientes hemos asistido al esfuerzo de los poderes públicos por profundizar en las exigencias de la libertad religiosa en un Estado laico y social como el nuestro a través del desarrollo y la ampliación de la norma constitucional y de su legislación derivada, unilateral o acordada.

A partir del dato constitucional y de su valioso desarrollo normativo, suele decirse que la libertad religiosa es un derecho relativamente pacífico. Si con ello se quiere significar que la dialéctica Estado-Iglesia ya

5 Sobre este vidrioso tema, MotILLA DE LA CALLE, A., El concepto de confesión religiosa en el Derecho español. Práctica administrativa y doctrina jurisprudencial, Centro de Estudios Políticos y Constitucionales, Madrid 1999.

6 Leyes 24, 25 y 26/1992, de 10 de noviembre, por las que se aprueban los acuerdos de cooperación con la Federación de Entidades Religiosas Evangélicas de España, la Federación de Comunidades Israelitas y la Comisión Islámica de España.

7 Los acuerdos entre el Estado español y la Santa Sede sobre asuntos jurídicos, económicos, enseñanza y asuntos culturales y asistencia religiosa de las Fuerzas Armadas y el servicio militar de clérigos y religiosos, fueron firmados el 3 de enero de 1979 y ratificados el 4 de diciembre de 1979. 
no puede provocar, como antaño, la crisis del sistema constitucional del Estado, no hay mayores inconvenientes en aceptar esa afirmación. Pero si se pretende expresar que la libertad religiosa se halla hoy plenamente protegida en nuestro ordenamiento, esa afirmación no puede compartirse. Sin afán provocativo alguno, cabe afirmar, a nuestro juicio, que la libertad religiosa es uno de los derechos fundamentales que más problemas tiene planteados en la actualidad. Problemas que aluden tanto al ejercicio de este derecho fundamental, a su necesaria conciliación con otros derechos, bienes y valores de relevancia constitucional (nótese que algunas confesiones defienden doctrinas de muy difícil encaje constitucional ${ }^{8}$ ), cuanto a su titularidad, a la cuestión de quiénes son los sujetos activos de la misma, quiénes son "las comunidades" a las que se refiere el artículo 16.1 CE. Y todo ello sin perder de vista que, a los más de veinticinco años de aprobada la Constitución, la Iglesia católica es, sigue siendo, un sujeto privilegiado del sistema español de protección de la libertad de culto y religión. Se diría que una realidad jurídica, fundada en los acuerdos del año 1979, a la que no se le aplican muchas de las previsiones de la Ley Orgánica de 1980, lo que se ha traducido en un régimen acordado y unos beneficios de los que no gozan el resto de confesiones que han suscrito acuerdos. Como se ha dicho, el Estado español es todavía hoy un Estado en proceso de desconfesionalización ${ }^{9}$, lo que provoca disfunciones tangibles desde la perspectiva de la salvaguarda de la libertad religiosa. Falta, en suma, avanzar en dimensiones igualitarias de esta libertad ${ }^{10}$.

Aun cuando a menudo se presente como mera anécdota, otra interesantísima cuestión, de hondo calado constitucional, que tiene hoy planteada nuestro Derecho en la esfera religiosa es la de la celebración institucional de festividades religiosas, esto es, la de la reverencia o veneración solemne por el poder público y a través del culto público de los misterios de una religión. Hasta la fecha, dos sentencias del Tribunal

${ }^{8}$ Dan buena muestra de ello las dos sentencias del Tribunal Europeo de Derechos Humanos recaídas en el asunto del Partido de la Prosperidad y otros c. Turquía (sentencia de Sala de 31 de julio de 2001 y de Gran Sala de 13 de febrero de 2003).

9 Amorós AzPILICUeta, J. J., "Notas al proceso de desconfesionalización del Derecho Eclesiástico español", en VV.AA, Studi in memoria de Mario Condorelli, vol. I, Milano 1988, pp. 19-48.

10 Así, Llamazares Fernández, D., Derecho de la libertad de conciencia, Civitas, Madrid 1997; Souto PAZ, J. A., "La libertad religiosa: las relaciones Iglesia y Estado", en Cisneros Laborda, G. (et al.), La Constitución española de 1978: 20 años de democracia, Congreso de los Diputados, Madrid 1998, pp. 193-210; MARTín-Retortillo BAQUER, L., "El marco normativo de la libertad religiosa», Revista de Administración Pública, 148, Madrid 1999, pp. 7-40. 
Constitucional se han ocupado del tema. Una, la sentencia 177/1996, de 11 de noviembre de 1996, deniega el amparo solicitado por un militar que fue sancionado disciplinariamente por el incumplimiento de una orden de participación en una parada militar de homenaje a la Virgen. Otra, la recentísima sentencia 101/2004, de 2 de junio, concede el amparo impetrado por un subinspector del Cuerpo Nacional de Policía que fue obligado a tomar parte en una procesión religiosa en contra de su voluntad. En ambas, el Constitucional analiza si los pronunciamientos que rechazaron la pretensión de amparo judicial de los recurrentes parten de una adecuada concepción de la libertad religiosa y de algunas de las garantías complementarias que para su disfrute real contempla el texto constitucional. Amparos, pues, de los del artículo 44 LOTC, en los que se impugna la actuación judicial lesionadora del derecho consagrado en el artículo $16 \mathrm{CE}$ y en el que se pide al Constitucional que restablezca al recurrente en la integridad de tal derecho ${ }^{11}$. Y amparos, en fin, complejos, aunque concisos, como se verá, en su argumentación jurídica, y muy significativos, en los que, al hilo de la resolución de la demanda interpuesta, se reflexiona, a propósito de la cuestión que aquí nos ocupa, sobre el contenido y límites del derecho fundamental de libertad religiosa y sobre el alcance de la laicidad estatal y de la toma de conciencia del factor religioso por parte de las autoridades públicas.

Este trabajo no intentará, de ningún modo, ni resumir la bibliografía existente sobre la celebración institucional de actos religiosos, no muy abundante por otra parte, ni utilizarla en su totalidad. Su propósito es mucho más limitado. Trataré sencillamente de aportar algunas reflexiones personales sobre su licitud o ilicitud constitucional, nacidas de algunas lecturas, del estudio de los dos pronunciamientos antes mencionados $y$, a fin de cuentas, de la observación desde el exterior de una rica problemática en la que hasta ahora no había penetrado. En esta dirección, comenzaré por exponer el contenido de los principios constitucionales que nuestra norma fundamental sienta en materia de conciencia y religión, exposición obligada a la hora de calificar constitucionalmente un hecho que tiene presencia en el ordenamiento ${ }^{12}$; proseguiré dando cuenta de la solución adoptada por el

11 Oliver Araúso, J., "El recurso de amparo frente a actos y omisiones judiciales", Revista de Estudios Políticos, 120, Centro de Estudios Políticos y Constitucionales, Madrid 2003, pp. 89-93.

12 Vid, por ejemplo, AlCANTARILLA Hidalgo, F., "La celebración de actos religiosos en ceremonias solemnes militares: libertad religiosa y aconfesionalidad estatal», $R e$ vista Española de Derecho Militar, 70, Madrid 1997, pp. 13-44; MARTí SÁnCHEZ, J. M., 
Tribunal Constitucional en sus sentencias $177 / 1996$ y 101/2004, lo que nos permitirá trascender el plano puramente especulativo de la teoría y de los principios para aterrizar en el campo de la realidad y de los hechos; por último, insisto, realizaré algunas consideraciones personales en torno a esta doctrina y, en suma, al acomodo constitucional de la celebración institucional de festividades religiosas. Adelanto desde ya que, con el mayor respeto a la opinión expresada por el Tribunal Constitucional, discrepo de algunas de las conclusiones a las que llega en las dos sentencias mencionadas y trataré de justificar mi discrepancia.

\section{PRINCIPIOS CONSTITUCIONALES EN MATERIA DE CONCIENCIA Y RELIGIÓN}

El artículo 16 CE es el que más directamente contempla el fenómeno social religioso, dedicándole una regulación específica en sus líneas, claro está, esenciales. Aunque existan algunas discrepancias, no fundamentales, entre la doctrina científica española ${ }^{13}$, una somera lectura del citado artículo nos lleva a considerar, como antes se apuntó, que son cuatro los principios que el constituyente sentó en materia de conciencia y religión: a) libertad religiosa; b) intimidad de las creencias; c) laicidad o aconfesionalidad; d) toma de conciencia de las creencias religiosas de la sociedad española; y e) cooperación.

\subsection{Libertad religiosa}

En la exégesis del artículo 16 CE, los autores admiten unánimemente que el principio primario consagrado por el constituyente en la regulación del factor social religioso es el de libertad religiosa. La decisión fundamental del constituyente en la materia es la del reconocimiento de la libertad de religión como un derecho subjetivo de carácter fundamental. Ello supone admitir que el resto de principios contenidos en ese mismo artículo son, en cierto sentido, principios dependientes del primario de libertad religiosa y que, en último término, a él están

"Las ceremonias religiosas en el ejército", en MARTínez-ToRRón, J. (ed.), La libertad religiosa y de conciencia ante la justicia constitucional, Actas del VIII Congreso Internacional de Derecho Eclesiástico del Estado, Granada, 13-16 de mayo de 1997, pp. 615-627.

${ }^{13}$ Calvo Álvarez, J., Los principios del Derecho Eclesiástico en las sentencias del Tribunal Constitucional, Navarra Gráfica, Pamplona 1998. 
subordinados. No existen discrepancias en cuanto al orden de prelación que debe establecerse entre los principios. Se admite el valor predominante de la libertad religiosa.

Pues bien, como ha expresado en reiteradas ocasiones el Tribunal Constitucional, la libertad religiosa, en cuanto derecho subjetivo, tiene una doble vertiente o dimensión. La vertiente interna "garantiza la existencia de un claustro íntimo de creencias y, por tanto, un espacio de autodeterminación intelectual ante el fenómeno religioso". La vertiente externa comprende un espacio de agere licere "que faculta a los ciudadanos para actuar con arreglo a las propias convicciones y mantenerlas frente a terceros". El reconocimiento de este espacio de libertad lo es "con plena inmunidad de coacción del Estado o de cualesquiera grupos sociales» ${ }^{14}$.

De las afirmaciones del Constitucional se deduce que la expresión genérica libertad religiosa encierra, al menos, tres posibilidades o aspectos distintos. Existe, en primer lugar, la libertad de creencias, por la que el individuo presta o rechaza su asentimiento íntimo a un sistema de verdades religiosas y se compromete a observarlas en relación con los aspectos trascendentes de la existencia humana. Ya que la garantía que presta el Derecho es fundamentalmente externa, toda persona tiene derecho a manifestar libremente las creencias que espontáneamente profesa y, por consiguiente, no puede ser obligado a manifestar las que no profesa (art. 16.2 CE) ni puede ser obligado a ocultar las que profesa. La libertad de creencias no alude al hecho puramente interior del íntimo sentimiento religioso, arreligioso o antirreligioso, sino a su expresión exterior.

Se da, en segundo lugar, la libertad de conciencia, entendiéndose por tal los criterios valorativos de las acciones humanas desde el punto de vista ético y moral y que señalan el límite entre el bien y el mal, entre las buenas y las malas acciones. La libertad de conciencia implica la traslación de las creencias del ámbito especulativo al nivel práctico, al campo del obrar humano. Alude al elemento ético o de compromiso de la actuación personal con las propias convicciones. También aquí la libertad de conciencia exige no ser obligado a actuar en contra de la conciencia ni ser impedido de obrar conforme a ella.

Cabe, en tercer lugar, una libertad de culto o litúrgica, que se traduce en el derecho a practicar externamente la creencia, en la facultad de rendir mediante ritos y ceremonias el homenaje debido a lo sagrado

14 Stc 154/2002 (fFJJ. 6, 7 y 8). 
trascendente en que la religión consiste. El culto puede ser privado (cuando se ejercita a la vista de pocos, familiar o domésticamente) y público (cuando se ejecuta de acuerdo con los ritos de una confesión religiosa y de manera socialmente ostensible). La libertad de culto es, en verdad, la manifestación exclusiva y singularísima del sentimiento religioso. El culto es la consecuencia de segundo grado de la libre opción religiosa.

Se puede hablar incluso de una cuarta posibilidad o aspecto, la libertad proselitista, que facultad al individuo a ganar partidarios o prosélitos para su doctrina o confesión. Atendiendo al criterio sentado por el Tribunal Europeo de Derechos Humanos en su sentencia Kokkinakis c. Grecia, cabría distinguir entre un proselitismo lícito, respetuoso con la propia libertad de conciencia de la persona a la que se intenta atraer o captar, y un proselitismo ilícito o abusivo, contrario a su dignidad y derechos de libertad ${ }^{15}$.

La libertad religiosa se refiere, pues, a tres cosas distintas, aunque íntimamente relacionadas entre sí: libertad para creer y no creer, para tener unas y otras convicciones religiosas; libertad para expresar $y$ manifestar esas convicciones; y libertad para comportarse de acuerdo a esas convicciones y para no ser obligado en contra de las mismas. Su núcleo esencial, al igual que ocurre con la libertad ideológica, es interno, pertenece a la esfera íntima del individuo y está constituido por la libertad que ha de tener toda persona para formar libremente en su interior sus propias convicciones en materia de religión. Tiene un segundo momento, externo, constituido por la libertad de manifestar al exterior esas convicciones, en cuanto la persona se ha decantado por una solución afirmativa ante el tema religioso. Un tercer momento, también externo, está constituido por el derecho de esa persona a comportarse conforme a la religión profesada y a no ser obligada a comportarse de forma contraria a las mismas.

Por otra parte, complemento intrínseco de la libertad religiosa es la igualdad en materia religiosa, de modo que cualquier gravamen o perjuicio que pudiera sufrir una persona, desde el punto de vista legal o desde el punto de vista de la aplicación de la ley, por razón de su profesión religiosa significaría menoscabo o detrimento de esta libertad. Todos los ciudadanos son, pues, titulares de la libertad religiosa en la misma medida o disfrutan por igual de esta libertad ${ }^{16}$.

\footnotetext{
15 STEDH Kokkinakkis c. Grecia (25-05-1993), parágrafos 31-49.

16 STC 24/1982 (FJ. 1).
} 
Ahora bien, ninguna libertad, por trascendente que sea, es absoluta o ilimitada, y tampoco puede serlo la libertad religiosa transgresora de la ley, de los derechos fundamentales de los demás y de unas condiciones materiales mínimas que propicien una convivencia ciudadana pacífica y aceptable. De ahí el límite del orden público que contempla el inciso final del artículo 16.1 CE.

Dice bien el texto constitucional cuando vincula dicho límite a las manifestaciones de la libertad, puesto que la adhesión interna a una religión, el sentimiento religioso íntimo o la profesión interior de un culto, son actos esencialmente incoercibles e incontrolables por el Derecho. Aunque sean contrarios al orden público escapan, por esencia, a las previsiones legales restrictivas o sancionadoras. En cambio, cuando las percepciones internas trascienden al orden exterior perturbando la convivencia, entonces han de operar los mecanismos limitadores de esa libertad.

El artículo 16 CE no aclara qué elementos integran la noción de orden público, pero sí introduce una primera matización de suma importancia. El orden público con capacidad para limitar las manifestaciones de la libertad religiosa no es cualquier orden público sino el «orden público protegido por la ley». La Constitución exige una delimitación legal de esa noción, como no podía ser menos al incidir sobre un derecho reconocido en la sección primera del capítulo II del título I (art. 53.1 CE). Así, pues, el orden público del artículo 16.1 CE no es un concepto vago e inconcreto que pueda aplicarse discrecionalmente por los órganos administrativos o jurisdiccionales, sino un concepto delimitado por las leyes, entendiendo por tales las normas generales emanadas del órgano legislativo a través del procedimiento establecido por la propia norma fundamental. Cualquier intervención del poder público en el ámbito de la libertad de religión invocando la cláusula del orden público debe tener adecuada cobertura en una ley previa. Éste es, precisamente, el significado primario de la reserva de ley del artículo 53.1 CE, que se superpone al poder público $y$, al propio tiempo, acota espacios de libertad de los ciudadanos frente a él.

De otro lado, y entrando ya en el contenido sustancial de la noción, el acatamiento de la Constitución y del resto del ordenamiento jurídico (art. 9.1 CE) es, de acuerdo con lo que ya indica la misma expresión orden, un principio básico elemental para la convivencia ciudadana. Podría así afirmarse que toda manifestación de la libertad religiosa está, en principio, permitida salvo que una ley formal y materialmente constitucional la haya prohibido. Establecida la necesaria sumisión al ordenamiento jurídico, a las autoridades legalmente constituidas y a 
sus agentes, para que la convivencia en colectividad sea prácticamente posible es necesario que se ofrezca y garantice a todo ciudadano el disfrute de una esfera básica de garantías materiales, esto es, un nivel mínimo material de pacífica convivencia, respetando su persona y bienes, su sosiego, librándole de violencias, intromisiones, peligros e incomodidades, ya que sólo así será la convivencia social una realidad aceptable y aceptada y una plataforma para el desarrollo personal y para el disfrute de los derechos fundamentales (art. 10.1 CE). Este nivel mínimo de garantías materiales de pacífica convivencia ciudadana, exigido por la conciencia social para que esa misma convivencia tenga un sentido positivo, es lo que más directamente puede entenderse por orden público, añadiéndosele aquél otro aspecto instrumental de la sumisión a la ley y al ordenamiento jurídico. Por lo demás, este nivel mínimo de condiciones materiales se concreta en la garantía de unos niveles determinados de seguridad en sentido estricto, o sea, de protección de personas y bienes, así como en la garantía de unos mínimos de salubridad que posibiliten biológicamente la vida colectiva, junto con unos niveles primarios de tranquilidad que hagan aceptable esta convivencia, dentro del respeto a los sentimientos básicos que la colectividad tenga asumidos como más profundos, es decir, la moralidad en sentido amplio. A todo ello alude expresamente el artículo 3.2 de la Ley Orgánica de Libertad Religiosa, al precisar que «el ejercicio de los derechos dimanantes de la libertad religiosa (...) tiene como único límite la protección del derecho de los demás al ejercicio de su libertades públicas y derechos fundamentales, así como la salvaguardia de la seguridad, de la salud y de la moralidad pública, elementos constitutivos del orden público protegido por la ley en el ámbito de una sociedad democrática».

Parece admitirse, por tanto, que para un efectivo y pleno disfrute de los derechos fundamentales, componente esencial del orden público, es imprescindible la base previa de una adecuada plataforma o nivel mínimo de garantías para la pacífica convivencia. Sería inútil reconocer formalmente a cada ciudadano el derecho a profesar cualquier religión si el ejercicio de este derecho pudiera verse de hecho perturbado o impedido mediante la violencia, la intimidación o la intromisión ejercida por otros ciudadanos. A su vez, el ejercicio de la libertad religiosa debe tener como límite natural el respeto a las personas y a los bienes ajenos, así como a las demás exigencias básicas de una vida colectiva pacífica presidida por el imperio de la ley. Esta doble perspectiva encuentra su punto de convergencia teórico en la idea de orden público. Sin imperio de la ley y sin garantía de convivencia pacífica no se puede ejercer la libertad individual, pero tampoco la libertad podrá ser una 
realidad tangible si la noción de orden público se deforma para utilizarla como cláusula arbitraria impeditiva de cualquier intento de manifestación pacífica de esa misma libertad ${ }^{17}$.

Se evidencia así que, en la actualidad, el orden público ha perdido la amplitud que tuvo durante mucho tiempo y, con ella, la virtualidad de servir de fundamento para el establecimiento de límites a los derechos fundamentales en términos manifiestamente incompatibles con el Estado democrático de Derecho. El orden público ha sufrido así una importantísima alteración sustancial; su morfología interna y su operatividad externa han cambiado radicalmente, siendo hoy una noción plenamente juridificada, mensurable y susceptible del más estricto control jurisdiccional ${ }^{18}$.

El orden público es, como se acaba de ver, el límite externo expreso que la Constitución señala a la libertad religiosa, pero eso no significa que no quepa ensanchar el ámbito de los límites de este derecho para incluir también a los que no se encuentran previstos de manera explícita en el artículo $16 \mathrm{CE}$ pero vienen impuestos por la propia lógica del sistema constitucional ${ }^{19}$. Podría así distinguirse, siguiendo el autorizado criterio de Alexy, entre cláusulas restrictivas de la libertad religiosa expresas y tácitas ${ }^{20}$. Sabido es, en efecto, que la Constitución establece por sí misma los límites de los derechos fundamentales en algunas ocasiones; en otras, el límite deriva de la Constitución sólo de manera mediata o indirecta en cuanto que ha de justificarse por la necesidad de proteger o preservar no sólo otros derechos fundamentales sino también otros bienes constitucionalmente protegidos. La consecuencia lógica de este planteamiento es que se puede limitar la libertad religiosa no ya para proteger el bien a que expresamente alude la Constitución - el orden público- sino incluso para amparar otros derechos constitucionales o bienes constitucionalmente reconocidos. A este respecto, por ejemplo, la STC 19/1985 admitió la posibilidad de que el principio de seguridad jurídica restrinja el ejercicio de la libertad de culto; y la STC 166/1996 afirmó que la libertad de conciencia religiosa se encuentra condicionada por las exigencias del régimen legal de la Seguridad Social, así como por las exigencias de la lex artis de la profesión médica.

17 Vid., por ejemplo, Martín-Retortillo Baquer, L., La cláusula del orden público como límite impreciso y creciente al ejercicio de los derechos, Civitas, Madrid 1975.

18 Bartolomé Cenzano, J. C. DE, El orden público como límite al ejercicio de los derechos y libertades, Centro de Estudios Políticos y Constitucionales, Madrid 2002.

19 STC 141/2000 (FJ. 4).

20 AleXY, R., Teoría de los derechos fundamentales (versión castellana de Ernesto Garzón Valdés), Centro de Estudios Constitucionales, Madrid 1993, p. 277. 
El punto de partida común de estas sentencias es, parece claro, la teoría de los límites inmanentes o implícitos de los derechos fundamentales, en virtud de la cual los derechos, por reconocerse en el seno de un ordenamiento jurídico coherente, han de conciliarse con otros bienes y valores que el propio ordenamiento protege y no pueden hacerse valer de modo absoluto frente a éstos. La teoría de los límites inmanentes pretende, en última instancia, hacer frente a lo que se califica como abuso de derecho.

El contrapeso de esta limitabilidad general de la libertad religiosa es que la limitación precisa ser justificada, y ello por el valor central de los derechos fundamentales en el sistema constitucional. Si los límites derivan de la unidad de la Constitución y los derechos constituyen el valor central del sistema, la limitación de éstos ha de estar objetivamente avalada por la realización de otros derechos, bienes o valores de relevancia constitucional. No cualquier bien o principio jurídicamente protegible puede actuar como límite de la libertad de religión, sino únicamente los contemplados por el constituyente. Si así fuera, resultaría muy sencillo vaciarla de contenido mediante la invocación de esos supuestos principios o bienes. La denominada ponderación de bienes es, por lo demás, el método propio para determinar en concreto, de conformidad con el principio de la concordancia práctica, cómo, cuándo y en qué medida debe ceder la libertad religiosa cuando entra en colisión con otro derecho fundamental o con un bien de relevancia constitucional. No se trata de establecer un orden jerárquico entre los distintos bienes o derechos, pues, salvo que la prioridad haya sido establecida de forma directa por la Constitución, hemos de suponer que en abstracto todos ellos tienen la misma importancia. Como expresa Alexy, el conflicto no se solventa declarando que uno de los bienes en conflicto no es válido, sino que, atendidas las circunstancias del caso, se establece una relación de precedencia condicionada ${ }^{21}$. Se trata de indicar las condiciones bajo las cuales un bien precede al otro. Bajo otras condiciones, la cuestión de la precedencia puede ser solucionada de un modo distinto. Se logra, por consiguiente, una jerarquía móvil que no conduce a la invalidez de uno de los derechos o valores constitucionales en conflicto, sino a la preservación de ambos, por más que, inevitablemente, ante cada conflicto sea preciso reconocer primacía a uno u otro $^{22}$. El control de la ponderación legislativa, judicial o administrativa corresponde, en último extremo, al Tribunal Constitucional mediante la

\footnotetext{
${ }^{21}$ Ibíd., p. 92.

22 Ibíd.
} 
valoración del derecho sacrificado y el derecho, bien o valor de relevancia constitucional garantizado.

De lo expuesto se desprende que toda restricción de la libertad religiosa, ya sea aduciendo la cláusula del orden público, ya sea invocando otros derechos o bienes constitucionales, ha de ser el resultado de una cuidadosa ponderación entre esa restricción constitucional posible y la fuerza expansiva de tal libertad, de suerte que aquélla se haya interpretado restrictivamente a favor de ésta, y resultando, en todo caso, proporcional de cara a alcanzar el fin que persigue. Todo acto o resolución que limite la libertad religiosa ha de asegurar que la medida limitadora sea necesaria para conseguir el fin perseguido y debe considerar la proporcionalidad entre el sacrificio del derecho y la situación en que se halla aquél a quien se le impone. La proporcionalidad se concibe así como un límite frente a la actividad limitadora de la libertad a fin de filtrar o moderar el sacrificio. Se trata de medir o comparar la relación que media entre dos magnitudes: los medios, limitadores, de un lado, y, de otro, la finalidad inmediata por ellos perseguida. Esto es: si el fin justifica los medios. Más exactamente, el medio ha de ser idóneo para la consecución del fin; necesario respecto de todos los medios útiles y susceptibles de alcanzarlo; y razonable o proporcionada stricto sensu la ecuación costes-beneficios en su resultado ${ }^{23}$.

\subsection{Privacidad de las creencias}

Tras el principio primario de libertad religiosa, el artículo $16.2 \mathrm{CE}$ consagra un derecho a no hacer, esto es, un derecho a no declarar que conlleva el que nadie pueda obligar, el que nadie se atribuya un derecho a exigir. Se trata de un derecho puramente negativo en el cual no se garantiza una conducta, un hacer de los individuos, sino una acción negativa ${ }^{24}$, una prohibición, de manera que se pone a salvo del Estado y de los terceros una determinada esfera de la vida individual. Por eso el derecho a no declarar sobre la propia ideología, religión o creencias se ejercita mediante la simple negativa a soportar la penetración o a responder a la pregunta. $Y$ es que siendo la religión un tema, más que personal, íntimo de cada cual, nadie debe introducirse en el interior de ese espacio de autodeterminación intelectual. El revelar la religión pro-

23 Sobre ello, GonzÁLEZ BeILfuSS, M., El principio de proporcionalidad en la jurisprudencia del Tribunal Constitucional, Aranzadi, Cizur Menor (Navarra) 2003.

24 Alexy, R., op. cit., pp. 189 y ss. 
fesada es un derecho personal y exclusivo del individuo, quien, lógicamente, puede negarse a declarar sobre ella.

La virtualidad del artículo 16.2 CE radica, a nuestro entender, en que anticipa y refuerza la tutela antidiscriminatoria que dispensa el artículo $14 \mathrm{CE}$ y, de modo inmediato, reacciona frente al pasado confesional del Estado español, en concreto frente a la obligación de realizar profesión pública de catolicidad en muchos de los documentos e instancias que se elevaban al poder público ${ }^{25}$.

Aunque la intención del constituyente parece clara, en su tenor literal este párrafo segundo del artículo 16 es susceptible de una interpretación restrictiva que la identifica con el llamado derecho al silencio, si bien ningún parlamentario la sugirió en el curso de los debates constituyentes. Antes bien, el diputado y ponente socialista, Gregorio Peces Barba, apuntó en su día que el párrafo que comentamos convertía en inconstitucionales las preguntas que se realizaban en ciertos formularios acerca de las creencias religiosas de los ciudadanos. A partir de esta precisión, la Constitución no sólo ampara el permanecer callado, sino que proscribe cualquier género de indagación destinada a descubrir lisa y llanamente cuáles son las creencias de una persona. La cuestión tiene relevancia porque garantizar el derecho al silencio puede resultar insuficiente, sobre todo en una Nación como la española con el pasado confesional que todos conocemos y con una mayoría cualificada de católicos. Y porque, en definitiva, rechazar la pregunta puede equivaler a manifestar una concepción religiosa o ideológica disidente, y eso es precisamente lo que trató de evitar el constituyente. La neutralidad ideológica y confesional del Estado excluye la posibilidad misma de la disidencia ideológica o religiosa. Como expresa el ATC 195/1983, «en el sistema de valores instaurado por la Constitución, la religión es un asunto privado, un problema íntimo, respecto del que se reconoce la más amplia libertad, como se desprende de los números 1 y 2 del artículo 16 de la propia Constitución ${ }^{26}$. Las creencias, cualesquiera que sean, "no pueden someterse a enjuiciamiento, y nadie, como preceptúa el artículo $14 \mathrm{CE}$, puede ser discriminado en razón de sus opiniones ${ }^{27}$. La intimidad de las creencias se revela, en último análisis, como una de las mayores garantías de los derechos de libertad e igualdad en sede religiosa puesto que nadie está obligado a declarar

25 Prieto SAnchís, L., "Las relaciones Iglesia-Estado a la luz de la nueva Constitución: problemas fundamentales", en GARcía DE ENTERRía, E.-PREDIERI, A., La Constitución española de 1978: estudio sistemático, Civitas, Madrid 1981, p. 337.

26 FJ. 3.

27 Ibíd.. 
sobre ellas. Desde este enfoque, la libertad declarativa no es sino un derecho derivado de la misma libertad religiosa que goza de formulación constitucional expresa por razones históricas. Los derechos de libertad e igualdad religiosa constituyen el fundamento de esta libertad declarativa.

Nótese, por otro lado, que el texto constitucional se refiere a declaración, no a manifestación. Esta última comprende toda una serie de conductas y actividades relacionadas con la fe profesada, entre las que sobresale el culto en cuanto conjunto de ritos y ceremonias litúrgicas con que se rinde homenaje a la divinidad. La declaración, en cambio, consiste en la simple expresión externa o aseveración de estar en posesión de una ideología o religión, esto es, en la puesta en conocimiento por medio del lenguaje oral o escrito de la pertenencia a una confesión religiosa o convicción moral. Sobre la manifestación ya se pronunció el inciso anterior del artículo $16 \mathrm{CE}$, al referirse al orden público en tanto límite externo expreso de las libertades ideológica y religiosa. Cabe observar, en cualquier caso, que si nadie puede ser obligado a declarar, a fortiori no puede ser obligado a manifestar sus creencias ideológicas o religiosas mediante conductas o actividades animadas por su ideología o por su fe religiosa. $Y$ tampoco se puede ignorar que toda manifestación tiene una eficacia declarativa evidente, por lo que no es descartable que la exigencia de una conducta relacionada con una fe religiosa pueda merecer algún reproche no sólo desde la perspectiva de la libertad religiosa sino también desde la óptica de la libertad declarativa. La línea divisoria entre declaración y manifestación no es tan clara.

Queda, de cualquier manera, a salvo la libertad para declarar sobre la ideología, religión o creencias cuando así la persona lo decida voluntariamente. Puede esto ocurrir cuando la persona decida actuar un derecho, generalmente de contenido religioso, cuyo ejercicio implica en la práctica una declaración de creencias. Así sucede, por ejemplo, cuando una persona opta por contraer matrimonio religioso, dedica su asignación tributaria a la Iglesia católica ${ }^{28}$, ejercita su objeción de conciencia por motivos de fe o solicita asistencia espiritual en situación de sujeción convivencial. En estos supuestos, hay una implícita declaración de creencias de carácter voluntario, pero a fin de realizar otros derechos de imposible ejercicio si no fuese de esta forma. La declaración sirve objetivamente, en estos casos, a la realización de la libertad religiosa del declarante, por lo que no es coherente pretender el reconocimiento

28 STS de 20 de octubre de 1997 (FJ. 1). 
de ese beneficio y negarse, al mismo tiempo, a declarar sobre la propia religión.

Finalmente, y como resulta obvio recordar, en razón de determinadas circunstancias y dentro de ciertos límites, puede resultar legítimo que tanto los poderes públicos ${ }^{29}$ como los particulares ${ }^{30}$ puedan condicionar determinados actos al conocimiento de la ideología o la religión de una persona cuando a ello les habilite el ejercicio de derechos constitucionales propios o la protección de valores e intereses generales de relevancia constitucional. Es posible que la ya aludida ponderación de bienes pueda inclinarse a favor de quien exige la declaración. No es tampoco la libertad declarativa un derecho absoluto o ilimitado.

\subsection{Laicidad}

La libertad religiosa, por otra parte, viene a configurar la posición jurídica en la que queda situado el individuo en su relación con los poderes públicos respecto de esa determinada manifestación de su personalidad que es la religión, quedando así clara la genuina protección que dispensa. Una protección que vendría delimitada por un doble comportamiento negativo del poder público: no interferencia en el proceso de formación de las íntimas convicciones del individuo ni obstaculización ni sanción de aquellas acciones que constituyan una legítima manifestación de su ideología o religión. De este modo, la dimensión orgánica de tal libertad se cifra en la neutralidad religiosa del poder público, de la que deriva la renuncia radical por el Estado a toda acción de adoctrinamiento moral o religioso, la imposibilidad para el ordenamiento de cualquier valoración preferente de las plurales expresiones religiosas de la comunidad y la imposibilidad de confusión entre funciones públicas y funciones religiosas ${ }^{31}$. Sobre el ámbito de las diversas opciones religiosas y de la actuación conforme a ellas, el Estado es radicalmente incompetente. Por eso cabe considerar a la libertad religiosa como una libertad eminentemente negativa. $Y$ es que la principal misión del Estado en la esfera de la religión es la de reconocer y garantizar la libertad de sus ciudadanos, encauzando el ejercicio social de la misma.

29 Vid., por todas, la STC 160/1987.

30 Bilbao UBillos, J. M., La eficacia de los derechos fundamentales frente a particulares, Centro de Estudios Políticos y Constitucionales, Madrid 1997, pp. 685 y ss.

31 SSTC 24/1982 (FJ. 1); 19/1985 (FJ. 4); 340/1993 (FJ. 4); STC 129/1996 (FJ. 2). 
La noción de laicidad indica, en efecto, lo contrario del Estado confesional, es decir, del Estado que adopta como propia una determinada religión y concede privilegios a sus fieles respecto de los creyentes de otras religiones y de los no creyentes. La laicidad incorpora la idea de la autonomía de las instituciones públicas y de la sociedad civil respecto del magisterio eclesiástico y de las injerencias de las organizaciones confesionales, así como el régimen de separación jurídica entre el Estado y la Iglesia como garantía de la libertad de los ciudadanos en su relación con ambos poderes. Así entendida, la laicidad es uno de los elementos característicos de la forma de Estado que recibe el nombre de democracia pluralista ${ }^{32}$. Forma de Estado que conlleva la existencia de unos valores propios y una actuación conforme a los mismos realizada a través del Derecho que la diferencian de la naturaleza y de los valores de los grupos ideológicos y religiosos. De ahí que el Estado aconfesional no pueda identificarse con ninguna religión o ideología ni, evidentemente, con ningún grupo religioso o ideológico.

A tenor de cuanto antecede, puede afirmarse que la tarea del Estado laico es doble. Positivamente, se compromete a garantizar la libertad religiosa como uno de los derechos fundamentales de la persona. Negativamente, es incompetente ante el acto de fe, de suerte tal que no puede convertirse en protector de los dogmas de una concreta religión. Como se aprecia, frente al derecho-principio de libertad religiosa, eminentemente positivo, el principio de laicidad o aconfesionalidad, expresivo de la plena independencia entre las Iglesias y el Estado, se nos muestra como restrictivo o limitador de la acción estatal. La laicidad es lo contrario de la confesionalidad y, por consiguiente, excluye tanto la confesionalidad en sentido formal como la confesionalidad en sentido material.

En primer lugar, y en cuanto opuesta a la confesionalidad formal o de iure, la laicidad desvincula al Estado de la profesión de una religión abrazada como verdadera. El Estado no debe reconocer expresamente en sus leyes fundamentales a una religión como oficial de la Nación. En el caso español, la Constitución de 1978 vino a poner fin a la confesionalidad proclamada en el artículo VI del Fuero de los Españoles de 1945, en el artículo I del Concordato de 1953 y en el principio II de la Ley de Principios del Movimiento Nacional de 1958.

32 Vid. los dos pronunciamientos ya citados del Tribunal Europeo de Derechos Humanos, recaídos en el asunto del Partido de la Prosperidad y otros c. Turquía (sentencia de Sala de 31 de julio de 2001 y de Gran Sala de 13 de febrero de 2003). 
En segundo lugar, y en tanto opuesta a la confesionalidad material, la laicidad excluye que los valores religiosos de una Iglesia o confesión sean patrimonio común de la sociedad que hayan de ser tutelados, así como que la legislación estatal deba adaptarse a las orientaciones o prescripciones religiosas referentes a la ordenación de los asuntos temporales. El Estado no debe inspirar su ordenamiento jurídico en la doctrinal y moral de una religión; "no debe imponer normas que sólo traigan causa en un concepto específico de una confesión religiosa» ${ }^{33}$. Se niega la incidencia de la idea de origen divino de lo justo y lo injusto sobre la conciencia colectiva y se proclama la libertad del poder político frente a cualquier moral religiosa impuesta desde fuera.

Ahora bien, esta desvinculación de la religión no tiene por qué significar el extremo contrario, esto es, la adopción de una postura hostil y persecutoria respecto del sentimiento religioso de los ciudadanos. Tal postura, que ha tenido sus manifestaciones en épocas concretas y en determinados países, estaría vedada en nuestro ordenamiento por la misma libertad religiosa de los ciudadanos, puesto que daría lugar a una suerte de confesionalidad ateística igualmente desautorizada por la Constitución. A este respecto, suele distinguirse la laicidad del laicismo: la primera, respetuosa con el fenómeno social religioso, y el segundo, hostil ante la religiosidad de los ciudadanos. La neutralidad, como se analizará a renglón seguido, no implica necesariamente hostilidad.

\subsection{La toma de conciencia de las creencias religiosas de la sociedad española}

Frente a la tesis de que el Estado laico opera al margen de toda influencia religiosa, el constituyente español, consciente de que las creencias, convicciones y sentimientos pueden informar las estructuras políticas, se abre a las exigencias sociales para formular, en el primer inciso del párrafo segundo del artículo 16.3 CE, un mandato que recae directamente sobre los poderes públicos y que les obliga a tener en cuenta las creencias religiosas de la sociedad española.

Apréciese que este mandato parte del supuesto de que la sociedad se deje influir en sus estimaciones colectivas por principios, valores o creencias de naturaleza religiosa. La toma de conciencia a que alude el inciso que comentamos hace referencia a las creencias de la sociedad española y por creencias hay que entender aquellas que hacen refe-

33 STC 129/1996 (FJ. 2). 
rencia a la dimensión trascendente del hombre. Creencias que habrán de tenerse en cuenta cuando tengan presencia social y precisamente en España.

Parece claro que la función inmediata de este inciso es la de servir de contrapunto al principio anterior de laicidad o aconfesionalidad, no sea que interpretado éste en su más riguroso sentido conduzca a un Estado indiferente $u$ hostil en el ámbito religioso. Ello comporta, en consecuencia, el abandono de toda postura que ignore, persiga o dificulte el desarrollo de la persona en su dimensión religiosa o que recluya lo religioso en el plano íntimo de la conciencia, lo confine a la vida privada de los individuos, negándole su dimensión social y comunitaria.

Así entendida, la locución «tendrán en cuenta las creencias religiosas de la sociedad española" contiene un mandato autónomo respecto del mandato siguiente, que se formula como concreción o consecuencia de aquél, pero sin agotarlo. La cooperación Estado-Iglesias no agota las formas de interesarse por las creencias religiosas de la sociedad española. Hay que reconocer, en todo caso, que la expresión es lo suficientemente amplia e indeterminada como para poder ser tomada en una acepción maximalista, de modo que la actividad de los poderes públicos debería estar informada por los principios religiosos de la sociedad, o en una acepción minimalista, en el fondo inoperante, que la redujese a una frase testimonial o, a lo sumo, la identificase con lo que es su consecuencia más inmediata, las relaciones de cooperación.

La acepción maximalista se desautoriza, en nuestra opinión, por sí sola, ya que no cabe duda de que cualquier interpretación del mandato que pudiera comprometer la laicidad debe rechazarse. La Constitución adopta una posición que valora el hecho social religioso, pero ello no significa que el Estado pueda hacer juicios de valor sobre la religión y ni mucho menos que pueda destacar a una de ellas con respecto a las demás ni que quepa la confusión entre funciones públicas y religiosas. Ya durante el debate constituyente se advirtió de que la preceptiva toma en consideración del factor religioso no debía derivar en una confesionalidad "encubierta»o "solapada».

Hecha esta precisión, para captar la relevancia jurídica del mandato sería necesario señalar los criterios prácticos que rijan su adecuada realización e incluso precisar los supuestos en los que se habría de considerar vulnerado. Por el momento, y a falta de asideros doctrinales suficientes, baste aquí decir que tener en cuenta no sólo equivale a considerar, sino también a actuar conforme o en consecuencia con las creencias religiosas. La valoración del hecho religioso por la Constitución parte del reconocimiento de la religión como fenómeno social- 
mente relevante. Percatado el constituyente de la tradición y de la presencia de este hecho en la sociedad española, le otorga relevancia. Se trata de una declaración constitucional que fundamenta la actividad de los poderes públicos sobre el factor religioso, pues la Constitución no se limita a aceptarlo o tolerarlo, sino que lo valora comprometidamente, no como lo hacía el régimen anterior, o sea, confesionalmente, ni como lo hace el Estado laicista, agresivamente, sino asumiendo dicho fenómeno social. Tener en cuenta el fenómeno social religioso no obliga al Estado a responder con una política de subordinación a factores confesionales, sino simplemente a proceder activamente respecto de ese fenómeno social dentro de las coordenadas de la laicidad estatal. Valorar activamente el hecho social religioso significa, en definitiva, aceptar socialmente la presencia de los acontecimientos y de las instituciones propias del hecho religioso y considerarlas a fin de que puedan satisfacerse los intereses de esta naturaleza de los individuos y de las comunidades $y$, en último extremo, pueda favorecerse el ejercicio real y auténtico de la libertad religiosa. De este modo, el Estado laico, en vez de entorpecer la integración de los creyentes, reconoce su dimensión social y los integra en la propia comunidad política. La toma de conciencia del hecho social religioso conduce a apaciguar la tensión en las relaciones entre las Iglesias y el Estado. Tensión que, como escribe Javier Pérez Royo, nace de la propia naturaleza social del hombre, integrado simultáneamente en una comunidad política necesaria (el Estado) y una comunidad religiosa contingente (la Iglesia) que, a menudo, dispone de una concepción integral del hombre ${ }^{34}$.

Contamos, por otro lado, con algunos ejemplos en que la legislación o las autoridades invocan este inciso, aunque algunos puedan ser también objeto de las relaciones de cooperación. Tales son la configuración de un estatuto jurídico específico para las Iglesias o confesiones; la observancia laboral de festividades religiosas; la prestación del juramento en determinados actos oficiales; la tipificación de los delitos contra la libertad de conciencia y los sentimientos religiosos, etc. Incluso el Tribunal Constitucional ha avalado la conformidad de algunos de estos supuestos ${ }^{35}$. Y nada de esto sería posible si el texto constitu-

34 Pérez Royo, J., Curso de Derecho Constitucional, Marcial Pons, Madrid 1999, p. 237.

35 Al margen de la invocación del artículo 16.3 CE en las SSTC 177/1996 y 101/2004 para avalar la presencia de autoridades civiles y militares en solemnidades religiosas o la programación de actos religiosos en la conmemoración de fiestas de carácter nacional, cuestión que se abordará in extenso más adelante, el ATC 180/1996 inadmite una demanda de amparo en la que se cuestionaba la constitucionalidad del delito de ofensas a la religión. El Tribunal concluye que «el carácter aconfesional del 
cional definiera un Estado rigurosamente laico que no tuviese en cuenta las creencias religiosas de la sociedad española.

\subsection{Cooperación}

El mandato de cooperación con el que se cierra el artículo 16.3 revela que la Constitución considera de interés público la satisfacción de las necesidades religiosas, a pesar de la existencia de individuos que no comparten dichas creencias. En la medida en que el Estado contemporáneo se autodefine como promotor de los derechos fundamentales de sus ciudadanos, comienza a eliminar los rescoldos o las reminiscencias laicistas y, simultáneamente, comienza a admitir la posibilidad de cooperación con las confesiones en los supuestos en que así lo exija el pleno ejercicio de la libertad religiosa. La cooperación parte del presupuesto de que lo religioso es una realidad social incuestionable que nace del ejercicio legítimo de un derecho subjetivo de carácter fundamental, y asume que el Estado y las Iglesias tienen funciones distintas $y$, consiguientemente, una autonomía propia. Pero ambos deben entenderse en pro de la libertad religiosa. La Iglesia y el Estado dejan, pues, de concebirse como dos líneas paralelas que no se encuentran nunca. Sí que se cruzan al cooperar ambos y establecer un marco que haga posible el disfrute auténtico de esa libertad.

En realidad, el mandato de cooperación tiene más bien un sentido programático y define la actitud o predisposición del ordenamiento estatal a establecer o promover ese tipo de relaciones. Unas relaciones que, en todo caso, han de mantenerse desde la recíproca independencia, sin que las funciones del poder público supongan invasión en los cometidos de las Iglesias y viceversa. La cooperación ha de salvar la distinción de estructuras y la diversidad de cometidos, temporales en un caso y religiosos en el otro, y expresa un tipo de relación en el que dos instituciones, distintas por su naturaleza y fines, han de coexistir, sin confundirse, en un régimen de armónica colaboración a fin de lograr la satisfacción de la libertad religiosa.

Se ha observado, en tal sentido, que este mandato, sin dejar de ser constitucional, no alcanza el mismo rango que los principios de libertad religiosa y laicidad. $Y$ esto en un doble sentido. Primero, en cuanto

\footnotetext{
Estado no implica que las creencias y sentimientos religiosos no puedan ser objeto de protección penal», siempre que esa protección no beneficie exclusivamente "a una confesión religiosa determinada». (FJ. 2).
} 
que las relaciones de cooperación deben supeditarse a los mencionados principios de tal manera que no puede contrariarlos. La libertad religiosa y la laicidad actúan como límites de la acción cooperativa del Estado $^{36}$. Y puesto que la cooperación tiene su límite en la libertad y en la laicidad quedan excluidas aquellas prestaciones que o bien no respeten el principio de voluntariedad o tengan por objeto la introducción de un trato injustificado entre creyentes y no creyentes, o bien impliquen la consecución de objetivos exclusivamente religiosos o la confusión de lo político y lo religioso. La cooperación del Estado con las confesiones debe llegar hasta donde sea necesario para hacer real y efectiva la libertad religiosa de los ciudadanos y superar los obstáculos que pudieran poner en peligro la realización de esa libertad, respetando siempre las exigencias derivadas de la laicidad. Éstas son las coordenadas delimitadoras del alcance del principio y de sus límites.

En segundo lugar, se dice que la cooperación no ostenta el mismo rango que el resto de principios que la Constitución sienta en materia de conciencia y religión por cuanto los de libertad religiosa y laicidad tienen un contenido bien definido, dando lugar a derechos subjetivos que pueden ser exigidos, mientras que las relaciones de cooperación son susceptibles de muy diversas formas de realización y su concreción admite un cierto margen de discrecionalidad política en función de las circunstancias y condicionamientos de cada caso, sin que pueda decirse que den lugar a verdaderos derechos subjetivos en orden a su verificación. Como afirmase la STC 93/1983, «el artículo 16.3 regula un deber de cooperación del Estado con la Iglesia Católica y demás confesiones y no un derecho fundamental de los ciudadanos".

Lo anterior, sin embargo, no puede llevarnos a considerar que sea constitucionalmente admisible calificar a priori como de mera oportunidad y, por tanto, no revisables jurisdiccionalmente ciertas cuestiones relacionadas con las relaciones de cooperación, so pretexto del margen de discrecionalidad que cabe reconocer al poder público en su concreción. Y es que la calificación de una potestad como discrecional excluye que el margen de apreciación derive en arbitrariedad. La discrecionalidad implica la atribución a la Administración por la ley de una cierta libertad de decisión a la vista de las circunstancias concurrentes en cada caso concreto, pero su actuación ha de ser responsable o, mejor dicho, ha de fundarse en motivos razonables, se compartan o no. Por su parte, los jueces, y en última instancia el Tribunal Constitucio-

36 SSTC 24/1982 (FJ. 4), 109/1988 (FJ. 2) y 340/1993 (FJ. 4). Asimismo, AATC 616/1984 (FJ. 3) y 480/1989 (FJ. 2). 
nal ${ }^{37}$, tienen la misión de controlar el ejercicio de la discrecionalidad y evitar así cualquier agravio contra el Derecho y, en el caso que nos ocupa, para la libertad religiosa, habida cuenta de que, insisto, el presupuesto de la cooperación no es otro que la realización de esta libertad. La cooperación es, por así decir, la vertiente positiva de la libertad de religión, que ha de ser hecha real y efectiva (art. 9.2 CE). El Estado colabora con las confesiones ex artículo 16.3 CE para la satisfacción de esa libertad y no para otra cosa.

Sobre tal base, las relaciones de cooperación entroncan con el concepto de Estado social que no sólo reconoce y garantiza los derechos sino que los promueve facilitando medios a los ciudadanos y a los grupos sociales para que la libertad y la igualdad tengan un contenido real. Es, en suma, la transformación del Estado constitucional contemporáneo la que explica la constitucionalización del principio de cooperación ${ }^{38}$. A diferencia del Estado liberal que asignaba derechos sin mención de contenido, el Estado social distribuye bienes jurídicos de contenido real. Se estima que lo único que puede asegurar la vigencia de los valores sociales es la acción estatal, para lo cual han de desarrollarse adecuados mecanismos institucionales. De ahí que el Estado social se conciba como un Estado que se responsabiliza de la procura existencial, esto es, de acometer las medidas que aseguren al hombre las posibilidades de existencia que no puede lograr por sí mismo. Lo que, en último análisis, se pretende es superar la posible contradicción entre la titularidad formal de los derechos y su ejercicio efectivo. Con otras palabras, el Estado social participa de la preocupación liberal por los derechos y las libertades individuales, a la vez que de las ansias por su efectividad.

La libertad religiosa no será una excepción y, junto a las técnicas negativas de la no interferencia, incorporará también técnicas positivas de promoción como las relaciones de cooperación. Ya no se la concibe sólo como un derecho público subjetivo que limita la actividad del Estado sino también como un principio para su acción legislativa y administrativa. En expresión de E. W. Böckenförde, la libertad religiosa deviene "una norma objetiva de principio o decisión axiológica» ${ }^{39}$. La

37 Así, por ejemplo, la STC 46/2001 (FFJJ. 7, 8 y 9).

38 García Pelayo, M., Las transformaciones del Estado contemporáneo, en sus Obras completas, vol. II, Centro de Estudios Constitucionales, Madrid 1991, pp. 1599-1600.

39 BÖCKENFÖRDE, E. W., Escritos sobre derechos fundamentales (traducción de Juan Luis Requejo Pagés e Ignacio Villaverde Menéndez), Nomos Verlagsgesellschaft, Baden-Baden 1993, pp. 104 y ss. 
cooperación Estado-Iglesias, en resumidas cuentas, tiene su fundamento inmediato en el mandato constitucional que las prescribe como consecuencia del deber de los poderes públicos de tomar en cuenta las creencias religiosas de la sociedad española (art. 16.3 CE). Pero buscar un fundamento más profundo nos lleva a la conclusión de que el mandato de cooperación implica el reconocimiento de que las confesiones religiosas desempeñan funciones de relevancia pública ${ }^{40}$ que han de ser consideradas por el Estado. Supondría admitir que el principio de cooperación es la proyección en el ámbito de la libertad religiosa de los postulados del denominado Estado social de Derecho y, en particular, de la concepción promocional de los derechos fundamentales.

\section{LA SOLUCIÓN DE LA JURISPRUDENCIA CONSTITUCIONAL}

Los principios de libertad religiosa, intimidad de las creencias, laicidad, toma de conciencia del factor religioso y cooperación constituyen el marco de certeza dentro del cual ha de desenvolverse toda política eclesiástica y, en general, toda actuación de los poderes públicos. Configuran, por así decir, el Derecho constitucional de lo religioso, con lo que se quiere significar que delimitan el tratamiento jurídico del factor religioso dentro de nuestro ordenamiento constitucional. $\mathrm{Y}$ a ellos, como no podría ser de otro modo, se alude en las SSTC 177/1996 y 101/2004 al enjuiciar la licitud constitucional de la celebración institucional de festividades religiosas.

Sin entrar ahora en el análisis de las consideraciones sobre la naturaleza subsidiaria del recurso de amparo, lo que escapa al tema que anima estas páginas, la doctrina sentada por el Tribunal Constitucional a propósito de la cuestión que aquí nos ocupa podría sintetizarse, si no me equivoco, en cuatro reglas o razones que deben servir de medida y a las que se ha de ajustar la acción de los poderes públicos para que resulte conforme a la Constitución. Únicamente en las siguientes coordinadas admite nuestro más alto Tribunal la expresión externa de la actitud de respeto en que consiste el culto religioso por parte del poder público.

Para empezar, el Constitucional, tras reiterar que la libertad religiosa (16.1 CE) garantiza no sólo "un claustro íntimo de creencias" 41 , es decir, "un espacio de autodeterminación intelectual ante el fenómeno

40 StARCK, C., "Raíces históricas de la libertad religiosa moderna», Revista Española de Derecho Constitucional, 47, 1996, p. 21.

41 SsTC $177 / 1996$ (FJ. 9) y 101/2004 (FJ. 3). 
religioso" ${ }^{42}$, sino también "una dimensión externa de agere licere que faculta a los ciudadanos para actuar con arreglo a sus propias convicciones y mantenerlas frente a terceros ${ }^{43}$, matiza que el artículo $16.3 \mathrm{CE}$ establece "un principio de neutralidad de los poderes públicos en materia religiosa que (...) veda cualquier tipo de confusión entre funciones religiosas y estatales ${ }^{44}$. La consecuencia inmediata de la neutralidad del poder público, ínsita en la aconfesionalidad del Estado, es «la posibilidad de ejercicio, inmune a toda coacción de los poderes públicos, de aquellas actividades que constituyan manifestaciones o expresiones del fenómeno religioso ${ }^{45}$, tales como el culto, la enseñanza religiosa, la reunión o manifestación pública con fines religiosos y la asociación para el desarrollo comunitario de este tipo de actividades. Al prescribir el artículo 16.3 CE que "ninguna confesión tendrá carácter estatal», está asegurando que los individuos, en el ejercicio de su libertad religiosa, cuenten con "un derecho a actuar en este campo con plena inmunidad de coacción del Estado ${ }^{46}$, cuya neutralidad se convierte de este modo en presupuesto para la convivencia pacífica de las distintas convicciones existentes en una sociedad plural y democrática.

En segundo lugar, el Constitucional considera, en contra de lo afirmado por las sentencias de instancia, que los actos en los que se negaron a participar los recurrentes eran de inequívoco contenido religioso ${ }^{47}$, ya que su exclusiva finalidad era celebrar el $V$ Centenario de la Advocación de la Virgen de los Desamparados, en un caso, y participar en el desfile procesional de la Hermandad Sacramental de Nuestro Padre Jesús, El Rico, de Málaga, en el otro. El primero, un acto organizado por la autoridad militar y destinado a la celebración, por personal militar, de una festividad religiosa; el segundo, un acto de naturaleza religiosa con participación policial.

En tercer lugar, y partiendo de esta base, el Tribunal sienta la regla de que «el artículo 16.3 CE no impide a las Fuerzas Armadas la celebración de festividades religiosas o la participación en ceremonias de esa naturaleza ${ }^{48}$. Admite, pues, la licitud constitucional tanto de la or-
42 Ibíd.
43 Ibíd.
44 Ibíd.
45 Ibíd.
46 Ibíd.
47 SSTC 177/1996 (FJ. 10) y 101/2004 (FJ. 4).
48 STC 177/1996 (FJ. 10). En verdad, menos clara al respecto se muestra la STC 101/2004; en ella no se contiene reflexión alguna en torno al encaje constitucional de la celebración institucional de festividades religiosas, si bien la insistencia en el prin- 
ganización de festividades religiosas como de la participación en ceremonias de esta naturaleza por razones de representación institucional. No se explicita su fundamento constitucional, se invoca genéricamente el párrafo tercero del artículo $16 \mathrm{CE}$, pero la resolución que se adopta, favorable a la celebración institucional de fiestas y solemnidades religiosas, es clara.

No obstante lo anterior - puntualiza a continuación-, "el derecho de libertad religiosa, en su vertiente negativa, garantiza la libertad de cada persona para decidir en conciencia si desea o no tomar parte en actos de esa naturaleza ${ }^{49}$. Decisión personalísima, a la que no se pueden oponer los poderes públicos, vinculados negativamente por el mandato de neutralidad del mismo artículo 16.3 CE. Por tanto, debe siempre respetarse el principio de voluntariedad en la asistencia, de suerte tal que nadie puede ser forzado a tomar parte en esos actos. $Y$ es que, en tanto expresión legítima de la libertad de religión, el acto religioso ha de nacer de la voluntad, y no por fuerza o necesidad extrañas a aquélla. Éste es el límite que ha de observar la acción estatal tanto en la organización como en la participación religiosa ${ }^{50}$.

Finalmente, y en cuarto lugar, no merece reproche alguno desde la perspectiva constitucional la imposición de la asistencia a un servicio militar o policial destinado a salvaguardar el orden público en un acto religioso con asistencia masiva de personas ${ }^{51}$. La excepción (la obligatoriedad) a la regla (la voluntariedad) vendría justificada por cuanto no se está ante un servicio especial orientado a celebrar una festividad

cipio de voluntariedad permite, a mi juicio, concluir que tampoco se cuestiona abiertamente la doctrina sentada en la 177/1996. El no haber profundizado en este tema es precisamente lo que motiva el voto particular del magistrado Roberto García-Calvo y Montiel, para quien, "como presupuesto o prius lógico", el Tribunal tendría que haber reiterado que "el artículo 16.3 CE no impide la celebración de actos religiosos ni la participación en actos de esa naturaleza por razones de representación institucional». Habrá que estar, por tanto, atentos en el futuro para valorar si el silencio de la STC 101/2004 acaba traduciéndose en un cambio de doctrina.

49 Sstc 177/1996 (FJ. 10) y 101/2004 (FJ. 4).

50 Se diría, en fin, que el Tribunal da por bueno el criterio recogido en los artículos 423 del Real Decreto 2945/1983, de 9 de noviembre, por el que se aprueban las Reales Ordenanzas del Ejército de Tierra, y 45 del Real Decreto 494/1984, de 22 de febrero, por el que se aprueban las Reales Ordenanzas del Ejército del Aire. En su virtud, las ceremonias militares de especial contenido religioso podrían ir precedidas de los actos religiosos que por tradición correspondan, si bien, con la debida antelación, se hará advertencia de que aquellos que no profesen la correspondiente religión queden dispensados de asistir al acto religioso.

51 STC 101/2004 (FJ. 4). 
religiosa, sino ante un servicio ordinario, desprovisto de toda connotación religiosa, y cuya finalidad es la de preservar la seguridad, la salubridad o la tranquilidad públicas en tanto elementos constitutivos del orden público protegido por la ley (art. 16.1 CE) ${ }^{52}$. Por lo demás, como circunstancias a tomar en cuenta para determinar la naturaleza especial u ordinaria del servicio cabría citar: a) el fundamento esgrimido para justificar la obligación de asistir al acto religioso; b) si el servicio contribuye a realzar la solemnidad de ese acto; y c) si el servicio se presta habitualmente con esas mismas características a otros grupos confesionales ${ }^{53}$.

Alcanzado el convencimiento de que el servicio carece de carácter religioso, no sería legítimo esgrimir la vertiente negativa de la libertad religiosa para eludir su cumplimiento. Cuestión distinta es que estuvieran claras las implicaciones de índole religiosa de la participación en un servicio especial, implicaciones que fundamentarían sobradamente la negativa de quien no profese una determinada religión a tomar parte en manifestaciones de culto de esa confesión, como es rendir honores o desfilar procesionalmente.

\section{VALORACIÓN CRÍTICA DE LA SOLUCIÓN DE LA JURISPRUDENCIA CONSTITUCIONAL}

Aun con el mayor respeto y consideración hacia la doctrina expresada por el Tribunal Constitucional en las sentencias 177/1996 y $104 / 2004$, creemos que algunos de sus fundamentos $y$, en definitiva, su valor pueden someterse a prueba. El cuestionamiento de esta doctrina nace de un entendimiento distinto de los límites dentro de los cuales debe desenvolverse la acción de los poderes públicos en la esfera religiosa, de acuerdo con las decisiones fundamentales enunciadas por el artículo $16 \mathrm{CE}$. Estamos completamente de acuerdo con el Constitucional en que la actuación de las autoridades enjuiciada en las dos sentencias examinadas supuso una clara vulneración de la vertiente negativa de la libertad religiosa de los recurrentes. Es incuestionable que el culto religioso ha de rendirse por espontánea voluntad y no por obligación o deber. Pero nuestra discrepancia nace de la consideración de que quizá no sea suficiente asegurar la voluntariedad del acto para satisfacer del todo las exigencias de la libertad religiosa y, en último análisis, de que quizá no resulte compatible con la laicidad estatal la

\footnotetext{
52 Art. 3.2 LOLR.

53 STC 101/2004 (FJ. 4).
} 
afirmación de que el artículo 16.3 CE faculta a los poderes públicos para celebrar festividades religiosas o participar en ceremonias de esta naturaleza.

\section{1. ¿Basta con garantizar el principio de voluntariedad para satisfacer plenamente las exigencias de la libertad religiosa?}

Como se ha visto, las SSTC 177/1996 y 104/2004 consideran que la negativa de los recurrentes a rendir honores y a desfilar procesionalmente estaba legitimada por su libertad religiosa, que incluye no sólo una dimensión interna de autodeterminación intelectual ante el fenómeno religioso, sino también una dimensión externa que faculta a los ciudadanos para actuar con arreglo a sus propias convicciones y mantenerlas frente a terceros. Desde esta perspectiva, la imposición de cualquier acto de culto contrario a las creencias religiosas de un individuo vulnera su libertad religiosa negativa.

Adviértase, no obstante, que el Tribunal soslaya la importante cuestión de si la vertiente negativa de la libertad religiosa y, en concreto, la libertad declarativa que consagra el artículo 16.2 CE se ve afectada aunque quede asegurado el principio de voluntariedad. Y es que, aun en el supuesto de que las autoridades hubiesen actuado de forma constitucional y no hubieran obligado a los recurrentes a rendir honores y a desfilar procesionalmente, éstos habrían tenido que exteriorizar sus creencias o ausencia de creencias para justificar su no participación en la parada militar o en el desfile procesional. El problema, pues, no reside en que sus superiores actuaran anticonstitucionalmente. Lo que es también inconstitucional es que las Fuerzas Armadas y el Cuerpo Nacional de Policía celebren una festividad religiosa, ya que en la organización o en la participación del poder público en una ceremonia religiosa está ya implícita la posibilidad de que un ciudadano tenga que verse obligado a declarar sobre su religión o creencias, contraviniéndose lo dispuesto en el artículo 16.2 CE. Para que ello no ocurriese debería interpretarse este mandato constitucional de tal manera que vedase la organización o la participación pública de festividades religiosas. Esto es lo que conceptualmente exige nuestro Estado constitucional y, en concreto, la libertad declarativa. Mutatis mutandis, a esta conclusión llegó el Tribunal Supremo americano en su sentencia West Virginia State Board of Education (1943): la organización por las autoridades de actos de contenido religioso puede invadir no sólo "la esfera del intelecto y del espíritu" sino también el ámbito de agere licere de la libertad de expresión. Obligar a alguien a participar en un acto de cul- 
to público en contra de sus creencias implica imponer de hecho una forma de declaración de las convicciones contraria a la vertiente negativa de las libertades de religión y de expresión ${ }^{54}$.

Todo ello enlaza, por otra parte, con la necesidad de interpretar de un modo más riguroso o estricto el sentido del párrafo segundo del artículo $16 \mathrm{CE}$. Alguna legislación, jurisprudencia y doctrina la conecta con la igualdad constitucional (art. $14 \mathrm{CE}$ ). Se viene a considerar que, ya que en ocasiones es muy difícil evitar la exteriorización de las creencias, lo que realmente interesa es asegurar que de la respuesta no se siga un trato discriminatorio. Pero, aun entendiendo las razones que llevan a esta interpretación en la denominada sociedad de la información, ha de subrayarse que el artículo 16.2 CE está conectado muy principalmente con el derecho a la intimidad (art. $18 \mathrm{CE}$ ), lo que obligaría a una interpretación más estricta o ajustada de su contenido. No se trata sólo de que la ideología o la religión puedan representar un motivo de discriminación sino de que pertenecen al ámbito de la intimidad, a la zona íntima y reservada de un individuo ${ }^{55}$, por lo que esa manifestación o exteriorización sólo resultaría exigible en aquellas situaciones en que sea necesaria para el ejercicio mismo de la libertad religiosa o para el desarrollo de actividades con ellas relacionadas. Así, por ejemplo, la objeción de conciencia por motivos religiosos, la asignación tributaria a favor de una Iglesia, la elección de asistencia religiosa en un establecimiento público, etc.

Con ocasión del debate constituyente se puso muy claramente de manifiesto que el artículo 16.2 CE prohibía no sólo el trato discriminatorio subsiguiente a la pregunta, sino igualmente la formulación misma de la pregunta y hasta, a propósito de la cuestión que anima estas páginas, la exigencia de actos con una eficacia declarativa incuestionable como pueden ser la rendición de honores o la participación en un desfile procesional. Así entendido, el artículo 16.2 anticiparía realmente la tutela antidiscriminatoria que dispensa el artículo $14 \mathrm{CE}$.

54 Véase Morán, G. M., La protección jurídica de la libertad religiosa en USA, Universidad de Santiago de Compostela, Santiago de Compostela 1989, pp. 84-86.

55 Así lo reconoce, con un criterio plausible a nuestro juicio, la Ley Orgánica 15/1999, de 13 de diciembre, de Protección de Datos de Carácter Personal. 
4.2. ¿Tolera la laicidad estatal tanto la celebración de festividades religiosas como la participación en ceremonias de esta naturaleza por razones de representación institucional?

La STC 177/1996 admite expresamente, de otra parte, la posibilidad de la representación institucional de los poderes públicos en festividades religiosas en base a lo dispuesto en el artículo 16.3 CE.

Pues bien, en nuestra consideración, y en contra de lo manifestado por el Constitucional, no resulta aceptable sostener, tras reconocer que los actos en los que fueron obligados a participar los recurrentes eran de inequívoco contenido religioso, que el principio de aconfesionalidad o neutralidad no impide a las autoridades la celebración de festividades religiosas o la participación en ceremonias de esta índole.

La laicidad se funda en una concepción secular y no sacra del poder político como actividad autónoma respecto de las confesiones religiosas, que, sin embargo, colocadas en un mismo plano de igual libertad, pueden ejercer su influjo político de acuerdo con su arraigo social.

El Estado aconfesional no se identifica con ningún credo religioso ni, consecuentemente, con ninguna confesión; ha de actuar conforme a unos patrones de conducta y unos valores propios, lo que lo diferencia muy nítidamente de la naturaleza de los grupos religiosos. Esos patrones, esos valores, junto a sus fines peculiares, son los que conforman la especificidad del Estado laico, su alteridad frente a las confesiones. Convendría no perder de vista que la función genuina de los idearios religiosos parciales no es la de hacer ciudadanos sino creyentes, en muchos casos con un germen ideológico contradictorio con los principios enunciados en la norma fundamental.

La laicidad indica, ante todo, lo contrario de confesionalidad, de ahí que no tolere que los valores o intereses religiosos se erijan en parámetros para medir la legitimidad de las leyes ni tampoco la confusión entre funciones estatales y religiosas. Las confesiones no pueden trascender los fines espirituales que le son propios y ser equiparables al Estado, ocupando una igual posición jurídica. Y del mismo modo en que rechaza los regímenes teocráticos, por medio de los cuales la Iglesia subordina a sí misma al Estado, el laicismo rechaza los sistemas en que el Estado sujeta a las Iglesias o las reduce a un ramo de su propia administración.

La relación entre lo temporal y lo espiritual, entre la norma y la fe, es de recíproca autonomía entre los dos aspectos distintos del pensamiento y de la actividad humana. El Estado, en cuanto garantiza a todas las confesiones libertad religiosa, sin establecer entre ellas ni un siste- 
ma de privilegios ni un sistema de control, no tutela solamente la autonomía civil respecto del poder religioso, sino que tutela igualmente la autonomía de las Iglesias respecto del poder temporal, que no puede imponer a los ciudadanos ninguna profesión u ortodoxia confesional. La Iglesia libre en el Estado libre: Cavour dixit. La libertad religiosa y la igualdad constitucional quedan así salvaguardadas.

El Estado laico es aquél que no suple o no coacciona el acto de fe. $Y$ que el Estado no pueda creer representa algo más que la descripción de una imposibilidad física; constituye más bien una exigencia de la adecuada protección de la libertad de conciencia religiosa. La libertad sólo puede ser real en una situación de igualdad y, sin duda, el fenómeno del Estado creyente distorsiona de tal modo la atribución de los derechos individuales que propiamente éstos tienden a quedar asfixiados bajo el peso del poder. La esencia de la libertad de religión radica, por el contrario, en la elevación del individuo a autoridad suprema en la esfera religiosa. La cuestión religiosa no es tarea de la competencia estatal y los poderes públicos deben ser neutrales.

A la luz de cuanto antecede, entendemos que hay motivos suficientes para considerar que la celebración y la participación activa del poder público en festividades religiosas implica una confusión de funciones contraria a la neutralidad proclamada en el artículo $16.3 \mathrm{CE}$, ya que implica la asunción del factor religioso en cuanto tal como algo propio por parte de un poder laico. Supone la implicación del Estado en algo que le es ajeno por completo a su propia naturaleza. Desconociendo la naturaleza íntima del acto de culto, como acto personal, el poder público concurre, sustituye y coacciona al organizar una parada militar de homenaje a la Virgen o al participar en un desfile procesional. No asume su incompetencia en la esfera religiosa, sino que homenajea reverentemente a lo que considera sagrado. No se comporta como Estado, lo que implica reconocer que es, por esencia, ajeno a toda valoración de lo religioso en el ejercicio de las funciones que tiene atribuidas, excepción hecha, claro está, de la garantía y promoción que debe prestar a la libertad religiosa de los ciudadanos. Lo decisivo, a la hora de descalificar la acción estatal, es la actitud y la práctica de religación con lo sagrado que evidencia la organización de la parada militar o la participación en un desfile procesional. Una actitud y una práctica, además, que quedan patentemente acreditadas si se analiza el fundamento de la obligación de participar en esos actos religiosos y las singulares características del servicio, especial, que se prestó.

En defensa de la postura mantenida por el Tribunal Constitucional no cabe alegar, entendemos, ninguno de los principios que, junto al de 
laicidad, consagra el artículo 16.3 CE: la toma de conciencia de las creencias religiosas de la sociedad española y la cooperación EstadoIglesias. Y ello, fundamentalmente, porque este artículo ha de ser interpretado en su conjunto. En virtud de la toma de conciencia del factor religioso y de la cooperación, el Estado asume una posición interesada y favorable al hecho religioso en cuanto contenido de un derecho fundamental, pero establece un límite claro: que ese interés no derive hacia la atribución de carácter estatal a confesión religiosa alguna ni hacia la confusión entre funciones públicas y religiosas. El límite de la toma de conciencia del factor religioso y de la cooperación está en la laicidad estatal. La aconfesionalidad no debe interpretarse hasta el extremo de imposibilitar la toma de conciencia y la cooperación, pero conserva la función de límite de una y otra, ya que el Estado no puede valorar positivamente lo religioso en cuanto tal.

El Estado sí que puede valorar activamente el hecho religioso, aceptar socialmente la presencia de los acontecimientos y de las instituciones propias de la religión y considerarlas a fin de que puedan satisfacerse los intereses de los individuos y de las comunidades, favoreciéndose así la integración de los creyentes y, de paso, la realización de la libertad religiosa. También puede, en cuanto especificación de la obligación general de los poderes públicos contenida en el artículo 9.2 CE, colaborar con los grupos confesionales para lograr esos objetivos. La naturaleza específica de las confesiones, conditio sine qua non para el ejercicio colectivo de la libertad religiosa, es la exclusiva razón de ser del principio de cooperación y no una pretendida preferencia de nuestro ordenamiento por lo religioso en detrimento de lo ideológico. Pero ni la toma en consideración del factor religioso ni la cooperación pueden avalar una actuación conjunta del Estado y de las Iglesias para celebrar actos de culto. El presupuesto de la toma de conciencia del hecho religioso y de la cooperación es la garantía y promoción de la libertad religiosa. Y cuando el Estado celebra institucionalmente un acto de culto no está asumiendo la satisfacción de la libertad de los ciudadanos, sino que concurre al acto de fe confundiendo funciones públicas y religiosas. Una cosa es que se organice y se preste asistencia religiosa a los individuos y a las comunidades que así lo soliciten y otra bien distinta es la celebración de festividades religiosas o la participación en actos de esta naturaleza por razones de representación institucional. Y es que debiera tenerse claro que en un Estado laico el acto de fe no compete al ente social sino a cada uno de sus componentes a título individual.

En definitiva, resulta claro que en los dos casos aquí enjuiciados no puede hablarse de una valoración por parte de los poderes públicos de 
las creencias religiosas de la sociedad, sino más bien de la exclusiva valoración de las doctrinas de una concreta religión y de su implicación en ellas, al decidir, por un lado, la celebración de un homenaje a una imagen que representa uno de los dogmas fundamentales de esa religión y, por otro, la participación en un desfile procesional que contribuye a realzar la solemnidad de un acto de culto de la misma confesión. No se garantiza la expresión del sentimiento religioso ni se promueve la libertad religiosa; sencillamente se está ante la expresión externa de una actitud de respeto a lo sagrado trascendente incompatible con la esencia del Estado laico.

Por eso, si en los casos de asistencia a actos de homenaje a un difunto (sea cual fuese su religión) o de asistencia a la inauguración de lugares de culto (sin excluir a ninguna confesión), la confusión entre funciones religiosas y estatales podría resultar discutible ${ }^{56}$, en los supuestos contemplados por las SSTC $177 / 1996$ y 104/2004, actos militares y policiales destinados a la celebración y participación por personal militar y policial en festividades religiosas, dicha confusión se da con toda nitidez y supone, por tanto, una vulneración palmaria de la laicidad o aconfesionalidad estatal.

\section{CONCLUSIONES}

1. El artículo $16 \mathrm{CE}$ es el que más directamente aborda el tratamiento jurídico-constitucional del factor social religioso, dedicándole una regulación específica en sus líneas esenciales. La fórmula escogida por el constituyente fue el resultado de una serie de redacciones en las que se produjo un claro deslizamiento desde la más estricta libertad y laicidad a la más abierta toma de conciencia de las creencias religiosas de la sociedad española y, en particular, la cooperación con las confesiones. Como se ha dicho, en el ánimo del constituyente español de 1978 influyó decisivamente la llamada cuestión religiosa, el deseo de superar arraigados demonios familiares de los españoles, a través de

56 Adviértase que, en tales casos, la presencia del poder público se debe al carácter institucional del homenaje al difunto o a la trascendencia social del acto de inauguración. Es claro que las autoridades participan en el acto religioso no tanto para realizar un acto de culto como para rendir honores fúnebres a la memoria del difunto o reconocer el arraigo lato sensu de una confesión religiosa. Teniendo en cuenta, por otra parte, la nula implicación religiosa que tiene la participación de las autoridades en dichos actos, cabe cuestionar, en nuestra consideración, su eficacia declarativa (art. 16.2 CE), así como que quepa invocar la vertiente negativa de la libertad religiosa para rehusar dicha participación. 
una fórmula con la que se ha conseguido en grado suficiente el disfrute de la libertad y la igualdad religiosa en el contexto de un Estado laico, aunque promotor de los derechos fundamentales de sus ciudadanos (art. 9.2 CE).

2. Teniendo presente el marco de certeza que en materia de conciencia y religiosa delimita el artículo 16 CE, las SSTC 177/1996 y 101/2004 admiten expresamente la celebración institucional de festividades religiosas, es decir, la reverencia o veneración solemne por el poder público y a través del culto público de los misterios de una religión. Para nuestro más alto Tribunal, el artículo 16.3 CE no impide a los poderes públicos la organización de festividades religiosas o la participación en ceremonias de esta naturaleza por razones de representación institucional. Ahora bien, «el derecho de libertad religiosa, en su vertiente negativa, garantiza la libertad de cada persona para decidir en conciencia si desea o no tomar parte en actos de esta naturaleza». Debe, pues, respetarse siempre el principio de voluntariedad en la asistencia, de modo que nadie puede ser forzado a participar en tales actos. El acto religioso ha de nacer de la voluntad y no por fuerza o necesidad extrañas a aquélla.

3. Sin embargo, en nuestra consideración, y en contra de lo manifestado por el Constitucional, el problema no está solamente en que las autoridades fuercen a participar a alguien en una festividad religiosa, sino que también es inconstitucional que las autoridades la organicen o participen porque contradice la libertad declarativa (art. 16.2 CE) y la laicidad estatal (art. 16.3). En efecto, aun en el supuesto de que el poder público actúe de forma respetuosa con la vertiente negativa de la libertad religiosa y no fuerce a un ciudadano a participar en una festividad religiosa, éste tendrá que exteriorizar sus creencias o ausencia de creencias para justificar por qué no participa en ella. Tendrá que desvelar el dato íntimo de su adscripción religiosa. De otra parte, partiendo de la base de que la laicidad impide la confusión de funciones públicas y religiosas, es claro que un acto público destinado a la celebración o participación de personal público en una festividad religiosa supone la expresión externa de una actividad de respeto a lo sagrado incompatible con la esencia del Estado laico. Debiera tenerse claro, a nuestro juicio, que el acto de fe no compete al ente social sino, en expresión del artículo 16.1 CE, a "los individuos" y a "las comunidades". La doctrina sentada en las sentencias 177/1996 y 101/2004 resulta, en suma, criticable por las razones siguientes: 1) porque la toma de conciencia del factor religioso (art. 16.3 CE) debe ser compatible con el principio primario de libertad religiosa (art. 16.1 CE), cuya garantía orgánica es la laicidad o aconfesionalidad estatal (art. 16.3 CE); 2) porque, sobre esta 
base, no existe bien o valor de relevancia constitucional que justifique el sacrificio de la libertad declarativa (art. 16.2 CE); 3) porque la celebración por las autoridades de actos religiosos implica mezclar funciones estatales y religiosas, violentándose así la laicidad estatal (art. 16.3 CE).

Alcanzado el convencimiento de que la celebración por los poderes públicos de una festividad religiosa tiene clara implicación religiosa, debiera reputarse inconstitucional por atentar contra la libertad declarativa y la aconfesionalidad del Estado, lo que sensu contrario implica admitir la licitud constitucional del servicio militar o policial destinado a salvaguardar el orden público en actos religiosos con afluencia masiva de personas $y$, tal vez, la corrección constitucional de la asistencia de las autoridades a actos de homenaje a un difunto y a actos de inauguración de lugares de culto.

Title:

"The celebration of religious acts by the State».

\section{Palabras clave:}

Libertad religiosa/laicidad/aconfesionalidad/relaciones Estado-Iglesias/privacidad religiosa.

\section{Key words:}

Religious freedom/non-establishment/secular State/Relationships between State and Churches/religious intimacy.

\section{Resumen:}

Una interesantísima cuestión de innegable trascendencia constitucional que tiene hoy planteada nuestro Derecho en materia de conciencia y religión es la de la celebración institucional de festividades religiosas, es decir, la veneración solemne, a través del culto, por el poder público de los misterios de una religión. Hasta la fecha, dos sentencias del Tribunal Constitucional se han ocupado del tema. Una, la STC 177/1996, deniega el amparo solicitado por un militar que fue sancionado disciplinariamente por el incumplimiento de una orden de parti- 
cipación en un homenaje a la Virgen. Otra, la más reciente STC 101/2004, concede el amparo interpuesto por un subinspector de Policía que fue obligado a tomar parte en una procesión religiosa en contra de su voluntad. Se trata de dos sentencias complejas y muy significativas, en las que el Tribunal Constitucional reflexiona sobre el contenido y límites de la libertad religiosa y sobre el alcance de la laicidad estatal. El presente trabajo enjuicia críticamente ambos pronunciamientos.

\begin{abstract}
:
The celebration of religious acts by the State is one of the most interesant questions of our Law in religious freedom matter. Is it constitutional that the State worships to a religion? Spanish Constitutional Court has recently passed two sentences answering to this question. The first of these sentences, STC 177/1996, decides the case of a military who was forced to pay tribute to the Virgin Mary. The second one, STC 101/2004, decides the case of a policeman who refused to take part in a religious procession. They are two complex and significant sentences, in which Spanish Constitutional Court theorizes on religious freedom and non-establisment. This article analyses critically both of them.
\end{abstract}

